\title{
Lysosomal enzyme tripeptidyl peptidase 1 plays a role in degradation of beta amyloid fibrils
}

Abbreviated Title: TPP1 role in A $\beta$ fibril degradation

Dana Cruz ${ }^{1}$, Mukarram El-Banna ${ }^{2}$, Amitabha Majumdar ${ }^{1}$, David E. Sleat ${ }^{2}$, Michelle

Muldowney ${ }^{1}$, Peter Lobel $^{2 \&}$, Frederick R. Maxfield ${ }^{1 \&}$

${ }^{1}$ Department of Biochemistry, Weill Cornell Medical College, New York, NY 10065.

${ }^{2}$ Center for Advanced Biotechnology and Medicine, Department of Biochemistry and Molecular Biology, Robert Wood Johnson Medical School, Rutgers University, Piscataway, NJ 08854.

\&To whom correspondence should be addressed:

Frederick R. Maxfield

Weill Cornell Medical College

Department of Biochemistry

1300 York Avenue

New York, NY 10065

Tel: (646) 962-2759

Fax: (646) 962-0519

Email: frmaxfie@med.cornell.edu

Peter Lobel

Center for Advanced Biotechnology and Medicine

Rutgers University

679 Hoes Lane

Piscataway, NJ 08854

Tel: (848) 445-9831

Fax: (732) 235-5083

Email: lobel@cabm.rutgers.edu 


\begin{abstract}
$\underline{\text { Abstract }}$
Alzheimer's disease (AD) is characterized by the accumulation of amyloid plaques surrounded by microglia. In cell culture, microglia internalize fibrillar $\beta$-amyloid but do not degrade it efficiently. Unactivated microglia have a relatively high lysosomal $\mathrm{pH}$, which impairs the activity of lysosomal proteases. Previous studies showed that activation of microglia with macrophage colony stimulating factor decreases lysosomal $\mathrm{pH}$ and enhances fibrillar $\beta$-amyloid degradation. We investigated the role of the lysosomal protease tripeptidyl peptidase 1 (TPP1) in cell culture and in a mouse model of Alzheimer's disease. Increased levels of TPP1 in unactivated microglia enhanced fibrillar $\beta$-amyloid degradation. Conversely, reduction of TPP1 led to decreased fibrillar $\beta$-amyloid degradation in activated microglia, macrophages, and other cells that degrade fibrillar $\beta$-amyloid efficiently. Reduction of TPP1 in an AD model mouse using a gene-targeted hypomorphic Tppl allele increased plaque burden. These results suggest that decreased TPP1 potentiates AD pathogenesis and that strategies to increase TPP1 activity may have therapeutic value.
\end{abstract}

Keywords: Microglia, Alzheimer's disease, lysosomes, mice, TPP1

\title{
$\underline{\text { Highlights }}$
}

*In microglia, TPP1 is important for the degradation of fibrillar $\beta$-amyloid.

*Increased TPP1 in microglia results in enhanced fibrillar $\beta$-amyloid degradation.

*In an AD mouse model, reduction of TPP1 led to increased amyloid plaque deposition. 


\section{Introduction}

Alzheimer's disease (AD) is characterized by the accumulation of $\beta$-amyloid plaques and tau neurofibrillary tangles. In AD patient brains, $\beta$-amyloid plaques are surrounded by microglia, the resident immune cells of the central nervous system (Hopperton et al., 2018; Taipa et al., 2017). In culture, microglia take up small particles of fibrillar $\beta$-amyloid (fA $\beta$ ) via Scavenger Receptor A (SRA) mediated endocytosis and deliver it to lysosomes but fail to degrade it efficiently (Chung et al., 1999; Majumdar et al., 2008; Masters et al., 2015; Paresce et al., 1996). In culture, untreated microglia continuously exposed to fA $\beta$ have lysosomes engorged with undigested fA $\beta$ (Paresce et al., 1997), resembling the deterioration of $A \beta$ clearance with time at later stages of AD (ElAli and Rivest, 2016). Microglia do not lack the lysosomal enzymes important for macromolecule degradation (Chung et al., 1999; Majumdar et al., 2008; Paresce et al., 1997; Paresce et al., 1996). However, their average lysosomal pH of 6 is higher than that of macrophages and other cell types (Majumdar et al., 2007). The less acidic lysosomal $\mathrm{pH}$ of the microglia is suboptimal for many lysosomal proteases (Solé-Domènech et al., 2016).

Mass spectrometry analysis showed that the first twelve N-terminal amino acids (the unstructured free end) of fibrillar $A \beta 42$ were degraded by microglia within 3 days, while degradation of the $\beta$-sheet region was very slow (Majumdar et al., 2008). In mice immunized against $A \beta$, microglia were responsible for $f A \beta$ clearance (Bacskai et al., 2001; Schenk et al., 1999). Transplantation of microglia into the hippocampus of A $\beta 42$-injected Wistar rats also increased $A \beta$ clearance (Takata et al., 2007).

Macrophage colony stimulating factor (MCSF) plays a critical role in the activation, maintenance and differentiation of microglia, the only cells in the brain that express the CSF receptor (CSFR1) (Erblich et al., 2011; Soulet and Rivest, 2008). Treatment of primary murine microglia with MCSF decreased their lysosomal $\mathrm{pH}$, and increased $\mathrm{fA} \beta$ degradation (Majumdar et al., 2007). This was attributable to increased lysosomal delivery of ClC-7, a chloride transporter necessary for complete lysosomal acidification (Majumdar et al., 2011). Consistent with this, MCSF treatment of AD mice (APPSwe $/ \mathrm{PS} 1)$ increased plaque clearance and improved performance in a spatial learning task (Boissonneault et al., 2009).

While some genetic risk factors for AD are known, causes of the late-onset form (LOAD) are still not understood (Kunkle et al., 2017; Lanoiselée et al., 2017; Tanzi, 2012). Clearance, rather than overproduction, of $\mathrm{A} \beta$ may be important for LOAD (Mawuenyega et al., 2010). Many enzymes have been described that degrade either monomeric or fibrillar A $\beta$. Addition of excess lysosomal enzymes to microglia led to increased degradation of fA $\beta$ (Majumdar et al., 2008). The lysosomal acidification caused by MCSF treatment (Majumdar et al., 2007) would also increase the activity of acid hydrolases.

Tripeptidyl peptidase 1 (TPP1), is a lysosomal enzyme candidate with a role in fA $\beta$ degradation (Dimitrova et al., 2017; Solé-Domènech et al., 2018). TPP1 is able to proteolyze fA $\beta$ efficiently at low pH (Solé-Domènech et al., 2018). Mass spectrometry analysis of peptides released from fA $\beta$ digested with TPP1 revealed several endoproteolytic cleavages including some within $\beta$-sheet regions that are important for fibril stability. Deficiency of TPP1 results in late infantile neuronal ceroid lipofuscinosis (LINCL), a childhood neurodegenerative lysosomal storage disease (Sleat et al., 1997). This enzyme is synthesized as an inactive zymogen that is 
stable at neutral $\mathrm{pH}$. After incubation at low $\mathrm{pH}$, the proenzyme rapidly undergoes autocatalytic activation (Golabek et al., 2008; Golabek et al., 2004; Guhaniyogi et al., 2009; Lin et al., 2001). The mature enzyme has a potent exopeptidase activity at $\mathrm{pH} 4$ to 5 , releasing tripeptides from proteins and oligopeptides with unsubstituted N-termini (Tian et al., 2006; Vines and Warburton, 1998). TPP1 also has endoproteolytic activity with a pH optimum of 3.0 (Ezaki et al., 2000).

In this study, we show that increasing TPP1 levels in primary microglia results in enhanced fA $\beta$ degradation. Conversely, in cells that normally degrade fA $\beta$ efficiently, reduction of TPP1 activity decreases $\mathrm{fA} \beta$ degradation. Moreover, in a transgenic mouse model of AD we show that reduction of TPP1 activity leads to increased plaque deposition in both the cortex and hippocampus. These results highlight the potential importance of TPP1 in AD.

\section{Materials and Methods}

\subsection{Materials}

Chemical reagents were purchased from the following companies: Alexa 488-wheat germ agglutinin (A488-WGA), Invitrogen (Carlsbad, CA); Aprotinin, Sigma-Aldrich (St. Louis, MO); A $\beta 1-42$ peptide (catalog \# H 1368), Bachem (Torrance, CA); Avidin-biotin complex horseradish peroxidase (ABC-HRP) solution (Vectastain Elite ABC kit), Vector Laboratories (Burlingame, CA); Cy3 dye, Amersham, GE Healthcare Bio-Sciences (Piscataway, NJ); Deoxyribonuclease I (DNase I), Worthington Biochemical Corporation (Lakewood, NJ); Dextran conjugated to fluorescein and rhodamine (70,000 Dalton molecular weight), Molecular Probes, Invitrogen (Carlsbad, CA); Diaminobenzidine, Vector Laboratories; Leupeptin, Sigma-Aldrich; MCSF, R \& D systems (Minneapolis MN); Pefabloc SC, Roche (Nutley, NJ); Pepstatin, Sigma-Aldrich; Shandon M1 solution, ThermoScientific (Waltham, MA); Trypsin (lyophilized powder), Worthington Biochemical Corporation. All other standard chemicals were purchased from Sigma-Aldrich unless otherwise stated. Purified recombinant human TPP1 was generated as described (Lin and Lobel, 2001). The tripeptidyl peptidase inhibitor Alanine-AlaninePhenylalanine-Chloromethylketone, AAF-CMK, was from New England Biolabs (Ipswich MA).

\subsection{Media}

Dulbecco's Modified Eagle Medium (DMEM), fetal bovine serum (FBS), L-glutamine, G418, McCoy's 5A medium, and penicillin-streptomycin solution were purchased from Gibco Laboratories (Grand Island, NY).

\subsection{RNAi Reagents}

siRNA sequences were Dharmacon SMART siGenome on-target plus set of 4 duplexes and scrambled siRNA negative control from Thermo Scientific (Lafayette, CO). Tppl targeting siRNAs were (1-GGGCUGAGUUUCAUCACUAUU, 2-CCUCUUCGGUGGCAACUUUUU, 3- ACUCAGACCUGGCUCAGUUUU, 4-GCACAUCAGGCAUCAGUAGUU). HiPerFect reagent was from Qiagen (Valencia $\mathrm{CA}$ ).

\subsection{Software}

MetaMorph image analysis software was from MDS Analytical Technologies, Universal Imaging (West Chester, PA). Bar graphs and plots were made in GraphPad Prism version 8 
software. P-values for the cell experiments were calculated using the Mann-Whitney U Test (GraphPad Prism). Actual P-values are reported unless they were below the maximum significant digits reported by the program, these are reported as $\mathrm{P}<1 \times 10^{-10}$. P-values for the stained brain slices were calculated using GraphPad Prism Linear Regression ANCOVA method. The $\mathrm{P}$ value reported for the Thio-S stained brain slices is the difference in the slopes of the experimental lines. FIJI (Image J version 2.0.0-rc-64/1.51s) open source image processing software was used for processing of Thio-S brain slice images.

\subsection{Cells}

All cells were maintained at $37^{\circ} \mathrm{C}$ in a humidified $5 \% \mathrm{CO}_{2}$ atmosphere. Primary mouse microglial cultures were isolated from the brains of one day old C57BL/6 mouse pups as described previously (Paresce et al., 1997). Briefly, brains were removed, minced with a scalpel blade in PBS, and sequentially digested with trypsin and DNase I. The resulting mixed glial culture was suspended in complete growth medium (DMEM, 10\% FBS, $1 \%$ penicillinstreptomycin and $4 \mathrm{mM}$ L-glutamine) in a $75 \mathrm{~cm}^{2}$ tissue culture flask, cultured for two weeks and microglia isolated using the shaking method (Giulian and Baker, 1986; Nakajima, 1989).

Microglia were plated at $70 \%$ confluency in complete growth medium on $35 \mathrm{~mm}$ coverslipbottom poly-D-lysine coated dishes and cultured for 1-2 days prior to use for experiments. For the MCSF-treated microglia, the complete growth medium was supplemented with $25 \mathrm{ng} / \mathrm{mL}$ MCSF. MCSF medium was used for each medium exchange. After plating, cells were maintained in MCSF medium for the duration of the experiment.

J774.A1 mouse macrophage-like cells and human osteosarcoma U2OS cells were from American Type Culture Collection (Manassas, VA). J774 cells were maintained as adherent cultures in complete growth medium (see above) in $10 \mathrm{~cm}$ petri dishes (polystyrene, not treated for tissue culture). U2OS-SRA cells (Sanchez-Carbayo et al., 2003) stably express the murine scavenger receptor A (Pipalia et al., 2017). The expression of SRA by these cells leads to very strong attachment by the cells to tissue culture optimized plastic surfaces, so these cells were maintained in $10 \mathrm{~cm}$ (non-treated) petri dishes with McCoy's 5A medium with $1.2 \mathrm{~g} / \mathrm{L}$ sodium bicarbonate, $10 \% \mathrm{FBS}, 1 \%$ penicillin/streptomycin. Selection pressure for SRA was maintained with $1 \mathrm{mg} / \mathrm{mL} \mathrm{G} 418$.

\section{6 fA $\beta$ Degradation Assay}

Fluorescence microscopy images were collected on a Leica epifluorescence microscope with an oil immersion 40X NA 1.25 objective (Leica Microsystems, Wetzlar Germany) equipped with an Andor iXon cooled CCD camera. The microscope was controlled by MetaMorph Imaging system software (Molecular Devices Universal Imaging, West Chester, PA).

To track $\mathrm{fA} \beta$ degradation, cells were incubated with fluorescently-labeled fibrillar A $\beta 42$ (Chung et al., 1999). The fluorescence intensity in the cells was a measure of how much labeled fA $\beta$ remained in each set of cells. The loss of Cy 3 signal indicated breakdown of the fA $\beta$ since Cy3 is quickly released from the cells if it is not attached to a larger protein (Paresce et al., 1997). This fluorescence degradation assay was comparable to degradation of radiolabeled fA $\beta$ $\left({ }^{125} \mathrm{I}-\mathrm{fA} \beta\right)$ by microglia (Majumdar et al., 2008). 
The A $\beta 1-42$ peptide was derivatized with Cy3 mono-reactive dye according to the manufacturer's instructions as described (Majumdar et al., 2007). Cy3-A $\beta$ (7 $\mu \mathrm{g} / \mathrm{mL}$ ) was incubated in DMEM with $10 \mathrm{mg} / \mathrm{mL}$ bovine serum at $37^{\circ} \mathrm{C}$ for 1 hour. Negative stain electron microscopy at high magnification showed that a $1 \mu \mathrm{g} / \mathrm{mL}$ Cy3 - A $\beta$ solution formed fibrils with average diameters of $10 \mathrm{~nm}$ (Paresce et al., 1996). These Cy3-labeled fibrillar aggregates of A $\beta$ are hereafter referred to as $\mathrm{Cy} 3-\mathrm{fA} \beta$. The $\mathrm{Cy} 3-\mathrm{fA} \beta$ solution was incubated for 1 hour with cells plated on a $35 \mathrm{~mm}$ coverslip-bottom dish at $37^{\circ} \mathrm{C}$. After 1 hour, excess Cy3-fA $\beta$ solution was washed off. Initial uptake by the cells was established for each experiment in three dishes fixed with $1 \%$ paraformaldehyde (PFA) immediately after 1 hour of loading with Cy3-fA $\beta$ (Majumdar et al., 2007). Experimental dishes were washed with complete medium and chased for various times with or without tested reagents. Cells were then fixed with $1 \%$ PFA, and the cell membranes were stained by incubation with $1 \mathrm{mg} / \mathrm{mL}$ A488-WGA in PBS for 10 minutes at room temperature. Cells were imaged by epifluorescence microscopy. Briefly, fields of cells were selected using the fluorescence from the A488-WGA stained cell borders. After selection, Cy3 images were acquired for each of these fields. Digital fluorescence images were analyzed using MetaMorph software. Images were background corrected, and the Cy3 integrated intensity measurement for each cell was recorded.

\subsection{RNAi in U2OS-SRA cells}

Scrambled (non-targeting) and Tppl targeting siRNA sequences were purchased from Dharmacon as SMART siGenome on-target plus set of 4 duplexes. Stock solutions of these siRNAs (100 $\mu \mathrm{M}$ in RNase-free, $\mathrm{pH} 7.4$ water) were prepared and frozen. U2OS-SRA cells were plated in 96 well plates at an initial density of $1 \times 10^{4}$ cells/well. On the following day the cells were transfected according to Dharmacon's standard transfection protocol. Individual or pooled $50 \mathrm{nM}$ siRNAs complexed with HiPerFect reagent (Qiagen) were added to the plated cells for 72 hours in antibiotic free complete medium at $37^{\circ} \mathrm{C}$ in $5 \% \mathrm{CO}_{2}$. After the transfection period, the medium in each well of the plate was changed and the cells assayed for ability to degrade and Cy3-fA $\beta$ as described above.

\subsection{TPP1 Activity Assay}

An endpoint TPP1 activity assay was conducted essentially as described (Sohar et al., 2000). Cell lysate (1.5 $\mu \mathrm{g}$ total protein) was incubated in a $100 \mu \mathrm{L}$ substrate solution of $100 \mathrm{mM}$ sodium acetate $150 \mathrm{mM}$ sodium chloride, $\mathrm{pH} 4.5$ buffer with $200 \mu \mathrm{M}$ Ala-Ala-Phe 7-amido-4methylcoumarin (AAF-AMC, Sigma), for 3 hours at $37^{\circ} \mathrm{C}$. Each sample was split into 4 wells of a 384 well clear bottom polystyrene plate and read on a Spectramax M2 plate reader (Molecular Devices) at $37^{\circ} \mathrm{C}$. The plate was read from the bottom using $351 \mathrm{~nm}$ excitation and $450 \mathrm{~nm}$ emission filters. The enzyme activity for each group of cells was expressed as the normalized value of arbitrary fluorescence units. All groups were normalized to the average fluorescence reading of the untreated cells.

\subsection{Animals}

All experiments were performed in compliance with the guidelines of the Institutional Animal Care and Use Committee of Robert Wood Johnson Medical School and Weill Cornell Medical College in accordance with the National Institutes of Health guidelines. All mice were in a C57BL/6 background. The J20 AD mouse model, B6.Cg-Tg(PDGFB-APPSwInd)20Lms/2J 
(Mucke et al., 2000), which expresses human APP with the Swedish (K670N/M671L) and Indiana $(\mathrm{V} 717 \mathrm{~F})$ mutations (APPSwInd) under the control of the human PDGFB promoter, was acquired from Jackson Laboratories. Mice hemizygous for the J20 transgene are designated as "AD" or Tg+. These were crossed with C57BL/6 congenic Tpp1 mutant mice (Sleat et al., 2008; Sleat et al., 2004). Mice homozygous for the neo ${ }^{\mathrm{del}}$ Arg446HisTppl allele (designated Tpp1 ${ }^{\mathrm{f} / \mathrm{f}}$ ) have $<10 \%$ TPP1 activity, synthesizing normal levels of properly spliced mRNA that encodes a missense mutation (Arg446His). Mice homozygous for the neo ${ }^{\text {ins }}$ Arg446HisTppl allele (designated $\operatorname{Tpp~}^{-{ }^{-}}$) exhibit aberrant mRNA splicing and have $<0.2 \%$ TPP1 activity. In the absence of the $\mathrm{J} 20$ transgene ( $\mathrm{Tg}-$ ), the phenotype of all Tppl genotypes ( $\mathrm{Tpp}^{+/+,+/,+/ \mathrm{f} \text { and f/f }}$ ) exhibited no apparent differences up to the maximum age of 18 months (Sleat et al., 2008). Mice designated as having $>50 \%$ TPP1 activity have at least one wild type Tppl allele. Genotypes, TPP1 and Beta-galactosidase activities (normalized to protein levels, expressed as arbitrary units) were verified for all animals used in this study (J20, JAX protocol; TPP1and Betagalactosidase, Supplemental Table 1 (Sleat et al., 2008; Sleat et al., 2004)). Male and female mice were used for all experiments described (Supplemental Table 1).

\subsection{Plaque Deposition in Mice}

The following procedure was adapted from ( $\mathrm{Li}$ et al., 2004). Tissue from the cerebrum was postfixed overnight in 4\% PFA. The following day, the fixed brain was moved to a $30 \%$ sucrose solution at $4^{\circ} \mathrm{C}$ for at least 24 hours until the brain sunk to the bottom of the vial. The brains were snap frozen in Shandon M1 solution (ThermoScientific, Waltham MA), stored at $-80^{\circ} \mathrm{C}$, and maintained at $-20^{\circ} \mathrm{C}$ overnight prior to sectioning. Sequential $40 \mu \mathrm{m}$ coronal sections were cut through the frozen sections with a cryostat (Bright Instruments model OTF5000, Huntington, England). Slices were stored in 0.1M PB, 30\% Ethylene Glycol, 30\% sucrose, at $-20^{\circ} \mathrm{C}$ in 24 well plates.

For fluorescence analysis of the plaques, slices from mouse brains 10 months (300 days) of age or older were stained with Thioflavine S (Thio-S, Sigma). Slices were washed with 0.1 M PB three times, stained in $0.005 \%$ Thio-S in $0.1 \mathrm{M}$ PB for 15 minutes, then washed three times for 5 minutes each in $0.1 \mathrm{M}$ PB. Slices were mounted on glass slides and imaged with a Hamamatsu Nanozoomer at 20X at the NYULMC DART Experimental Pathology Research Lab, NYU Langone Medical Center.

Images of individual brain slices were opened and processed with FIJI software (Schindelin et al., 2012). A threshold was set to separate plaques from the background of the image. Plaques were scored based on minimum size criteria $(22 \mu \mathrm{m})$ and circularity $(0.2-1.0$, calculated as: circularity $=4 \pi\left(\right.$ area $/$ perimeter $\left.^{2}\right)$, a value of 1.0 indicates a perfect circle $)$. The region containing the hippocampus and cortex for each brain slice was hand drawn for each brain slice. The percent plaque coverage was determined based on the area covered by plaques in the region divided by the defined area of the cortex or hippocampus (Measure function in FIJI). The plaque count was determined using the Analyze Particles function of FIJI. All numbers were exported to Excel, separated by individual slice.

\section{Results}

\subsection{Uptake of TPP1 by microglia enhances degradation of fA $\beta$}


Exogenously added recombinant TPP1 is internalized by cells (via the mannose-6phosphate receptor) with an apparent $\mathrm{EC}_{50}$ for uptake of $1.5 \mathrm{nM}$ (Lin and Lobel, 2001). To determine if increased levels of TPP 1 would enhance degradation of $\mathrm{fA} \beta$, we loaded mouse microglia with Cy3-fA $\beta$ for one hour and then incubated the cells with or without $100 \mathrm{nM}$ recombinant TPP1 for 72 hours. Untreated microglia degraded negligible amounts of the Cy3fA $\beta$ during this time, but the additional TPP1 led to degradation of more than half of the internalized Cy3-fA $\beta$ (Figure 1).

\subsection{Tripeptidyl peptidase activity is required for efficient degradation of fA $\beta$}

Macrophages and MCSF-activated microglia can efficiently degrade fA $\beta$ (figure 2). We tested whether tripeptidyl peptidase inhibition would affect $\mathrm{fA} \beta$ degradation by these cells. We also tested this in an osteosarcoma cell line that stably expressed Scavenger Receptor A (U2OSSRA) (Pipalia et al., 2017; Sanchez-Carbayo et al., 2003). The inhibitor Alanine-AlaninePhenylalanine-Chloromethylketone (AAF-CMK) inhibits TPP1 (Junaid et al., 2000; Vines and Warburton, 1998) and TPP2 (Lévy et al., 2002). Fifty micromolar AAF-CMK was added to the growth medium of all three cell types for 1 hour before $\mathrm{Cy} 3-\mathrm{fA} \beta$ was added to the cells. The cells were then chased in medium with or without the inhibitor for 48 hours after Cy3-fA $\beta$ uptake. This led to a nearly complete inhibition of $\mathrm{Cy} 3-\mathrm{fA} \beta$ degradation as measured by release of $\mathrm{Cy} 3$ from the cells (Figure 2A-C). Untreated cells degraded $60-75 \%$ of internalized Cy3-fA $\beta$ within 48 hours.

\subsection{RNAi knockdown of TPP1 reduces $f A \beta$ degradation}

We further tested the role of TPP1 in fA $\beta$ degradation by reducing its expression in cells by RNA interference (RNAi). In these experiments, we used U2OS-SRA cells due to the difficulty in efficiently transfecting J774 macrophage cells or microglia. The U2OS-SRA cells degrade Cy3-fA $\beta$ almost as well as J774 macrophages or MCSF-treated microglia (Figure 2). The SRA expression by this cell line allows it to take up fA $\beta$ and deliver it to lysosomes (Majumdar et al., 2011).

We tested multiple siRNA sequences that targeted Tppl and pooled two to knock down TPP1 expression in these cells. The TPP1 activity in cells treated with these siRNAs for 72 hours was about $30 \%$ of the activity in untreated cells or cells treated with scrambled siRNA (Figure $3 \mathrm{~A}$ ). The cells were incubated for 72 hours with the siRNAs (or controls) and then loaded with Cy3-fA $\beta$ for one hour and chased for 24 hours. The initial uptake of Cy3-fA $\beta$ by untreated and siRNA treated cells was pooled since the different conditions did not alter uptake. After siRNA treatment, Cy3-fA $\beta$ degradation was inhibited almost completely compared to control U2OSSRA cells (Figure 3B). Two sets of controls were used in these experiments. One set of cells was treated with non-specific (scrambled) siRNA. The other set was not treated with any siRNA. Both the untreated cells and those treated with scrambled siRNA degraded more than half of the Cy3-fA $\beta$ after a 24 hour chase period. Thus, loss of TPP1 expression greatly reduces degradation of internalized fA $\beta$.

\subsection{Microglia from $\operatorname{Tpp~}^{-/-}$mice show impaired degradation of fA $\beta$}

Previous studies indicate that MCSF treatment of wild type microglia significantly enhances their ability to degrade fA $\beta$ (Majumdar et al., 2007). MCSF treated microglia have 
more acidic lysosomes (Majumdar et al., 2007). This lower lysosomal pH creates a more optimal environment for the function of lysosomal enzymes. To investigate the participation of TPP1 in this process, we performed parallel experiments on primary microglia from wild type and $\mathrm{Tpp}^{-/-}$ mice. The TPP1-deficient microglia were only able to degrade $\sim 15 \%$ of the endocytosed fA $\beta$ in 72 hours as compared to $\sim 70 \%$ degradation in the wild type microglia (Figure 4 ).

\subsection{Effect of TPP1 on Plaque Deposition in an AD Mouse Model}

We crossed J20 AD model mice (designated Tg+) with strain-matched lines that had reduced TPP1 expression levels. If TPP1 expression is important for the degradation of A $\beta$ plaques, mice that lack normal levels of expression should have increased A $\beta$ plaque load. Tpp $1^{\mathrm{f} / \mathrm{f}}$ mice have $<10 \%$ of wild-type TPP1 activity (Supplemental Table 1). The two groups of control animals were Tg+ with $50-100 \%$ of normal expression of TPP1 (Tpp1 $1^{+/+}$or $+/ f$ ) and mice that did not express the APP transgene (Tg-). For these non-AD mice, Tpp ${ }^{+/+}, T_{p p 1^{+/ f}}$, and $T p p 1^{\mathrm{f} / \mathrm{f}}$ animals did not have plaque deposition and thus we pooled mice with all levels of TPP1 expression for the non-AD group.

We labeled sections with Thio-S to stain the amyloid plaques (Figure 5A). Quantitative comparisons of the Thio-S labeled plaques in the brains of the mice aged 300 days or older showed increased plaque coverage of the cortex and hippocampus with age, and mice with limited TPP1 activity expression had greater plaque load than mice with TPP1 activity of $50 \%$ or more (Figure 5, Supplemental Table 1). The percent of both the cortex and hippocampus covered by plaques was significantly higher in mice with limited TPP1 activity compared to mice that had TPP1 activity of 50\% or more (Figure 5B and D). The number of plaques increased with age in both the cortex and hippocampus (Figure 5C and E). Plaque numbers were significantly greater in the cortex of mice with limited TPP1 activity while in the hippocampus the slopes were not significantly different $(\mathrm{P}=0.1058)$, but the trend can still be seen of an increase in plaques in the AD mice that have limited TPP1 activity.

\section{Discussion}

In Alzheimer's disease, the net accumulation of $A \beta$ is due to an imbalance between its production and degradation. Several mutations in humans and animal models increase the rate of A $\beta$ production (Saido and Leissring, 2012). Most of the early-onset autosomal dominant AD results from pathogenic genetic mutations in APP that alter its proteolytic processing and endolysosomal transport, leading to increased A $\beta$ production (Kunkle et al., 2017; Lanoiselée et al., 2017). Other mutations that result in increased production of $A \beta$ and that have been associated with increased incidence of AD include PSENs 1 and 2, components of the $\gamma$-secretase complex, and BACE 1. These mutations increase plaque burden and are associated with increased risk of dementia.

The regulation of $A \beta$ degradation is still an active area of research. The $A \beta$ peptide is produced mostly by neurons and is found both inside cellular organelles and in the extracellular space (Dominguez et al., 2005). A $\beta$ spontaneously forms $\beta$-sheet fibrils that can aggregate and associate with other proteins to form plaques (Glenner and Wong, 1984). It is then taken up by many cell types and accumulates in their lysosomes. 
There are several proteolytic enzymes that have been implicated in degradation of $A \beta$ (reviewed in (Saido and Leissring, 2012)). Decreasing the levels of several of these in mouse models resulted in increased endogenous cerebral $A \beta$, which was additive and gene dose dependent. Thus, more than one enzyme may be critically required for $A \beta$ degradation, and there may be little reserve capacity for the clearance of $A \beta$ in the brain (Saido and Leissring, 2012).

The $\beta$-sheet structure of $\mathrm{fA} \beta$ makes it protease resistant, protecting most of the sequence from degradative enzymes. Disruption of the $\beta$-sheet would provide access to the peptide bonds that are cleaved by lysosomal proteases. The most studied lysosomal enzymes in AD, Cathepsins $\mathrm{B}$ and $\mathrm{D}$, were found in extracellular A $\beta$ plaques (Cataldo and Nixon, 1990; Mueller-Steiner et al., 2006). Cathepsin $B$ is able to cleave fibrillar $A \beta$ with multiple cut sites just before and within the $\beta$-sheet region both in vivo and in vitro (Mueller-Steiner et al., 2006). Cathepsin B knock-out mice that also expressed human APP had increased hippocampal A $\beta$ plaque load (MuellerSteiner et al., 2006). Upregulation of cathepsin B in hippocampal neurons of APP/PS1 transgenic mice reduced $A \beta$ plaque load and showed memory improvement (Embury et al., 2017). Cystatin $\mathrm{C}$, a cysteine protease inhibitor, has also been genetically linked to late-onset AD (Bertram et al., 2007; Sun et al., 2008). In mice, downregulation of cystatins led to reduced A $\beta 1-42$ levels (Sun et al., 2008; Wang et al., 2012; Yang et al., 2011). Cathepsin D, an aspartic protease, cuts A $\beta 42$ within the $\beta$-sheet region (Hamazaki, 1996; Mackay et al., 1997).

The lysosomal protease TPP1 has endopeptidase activity in addition to its function in removing tripeptides from the unsubstituted $\mathrm{N}$-termini of proteins and peptides. In vitro studies indicate that TPP1 cleaves fibrillar A $\beta$ at numerous sites including those in the $\beta$-sheet region (Solé-Domènech et al., 2018). TPP1 and Cathepsin B have overlapping cut sites. Some of these cleavages are within the KLVFF hydrophobic core of the $\beta$-sheet and are the most likely to destabilize it. Further degradation of $A \beta$ fibrils can then occur due to the action of many lysosomal enzymes after the protective $\beta$-sheet structure has been disrupted.

We found that delivery of excess TPP1 to microglial lysosomes by endocytosis of exogenous enzyme increased the ability of unactivated microglia to degrade fA $\beta$. Even though the endoprotease activity of each TPP1 enzyme would remain low at the $\mathrm{pH}$ of microglial lysosomes, this can be compensated by a large increase in the abundance of the enzyme. Although unactivated microglia are very poor at degrading fA $\beta$, several other cells types (including macrophages, activated microglia, and U2OS-SRA cells) can degrade fA $\beta$ in their lysosomes (Majumdar et al., 2008; Majumdar et al., 2007). Inhibition of TPP1 in these three cell types with the tripeptidyl peptidase inhibitor AAF-CMK led to almost complete loss of fA $\beta$ degradation. Similarly, siRNA reduction of TPP1 expression greatly reduced fA $\beta$ degradation in U2OS-SRA cells. Thus, levels of TPP1 activity play a critical role in the degradation of fA $\beta$. It is not clear which role each enzyme plays, but it is possible that multiple cuts in the $A \beta$ attached to a fibril are required to release it efficiently.

We present data in the $\mathrm{J} 20$ transgenic mouse model of AD that show that TPP1 activity is also important for degradation of amyloid in vivo. There was a significant increase in the amyloid burden of $\mathrm{Tg}+$ mice with $<10 \%$ of normal TPP 1 activity. (Mice with $\leq 3 \%$ TPP1 do not survive long enough to develop plaques.) 
Currently, there are no reported associations of variations in TPP1 and AD in humans. However, as a member of the CLEAR (Coordinated lysosomal expression and regulation) network of genes regulated by TFEB (transcription factor EB), TPP1 expression increases with TFEB activation (Song et al., 2013), and modulation of lysosomal function by TFEB has been proposed as a potential target for treatment of AD based on animal results (Xiao et al., 2014). TPP1 levels vary with age and cell type. In the human hippocampus, the CA2/3 regions show the strongest immunoreactivity at a young age that weakens for adults but returns to higher levels at advanced age. The pyramidal neurons of the CA1 region also have weaker TPP1 expression than CA2/3 at all ages (Kida et al., 2001).

Based on multiple lines of evidence in this study that implicate TPP1 in the clearance of $\mathrm{fA} \beta$, elevating levels of this enzyme in microglia and/or other cells in the brain may be beneficial in reducing fA $\beta$ levels in the $\mathrm{AD}$ brain. This is particularly exciting given that cerebroventricular administration of TPP1 has been shown to be effective as an enzyme replacement therapy for LINCL (Schulz et al., 2018). However, the utility of this approach for AD remains to be demonstrated and it is possible that there are indirect effects arising from reduction of TPP1 in our in vivo studies. Recently, a transgenic mouse model has been developed that constitutively overexpresses TPP1 10-20 fold higher than wild-type levels (Nemtsova et al., 2018). This should allow direct evaluation of the potential therapeutic utility of TPP1 in fA $\beta$ clearance and amelioration of the AD phenotype.

\section{Acknowledgements}

The authors thank the laboratory of Dr. Lennart Mucke of The J. David Gladstone Institutes of San Francisco, CA for the use of the PDGF-hAPP (J20) transgenic mice. The authors would also like to thank Drs. Branka Brukner Dabovic and Cynthia Loomis of the NYULMC DART Experimental Pathology Research Lab (NYU Langone Medical Center) for imaging services. We also thank Harold Ralph and Dr. Sushmita Mukherjee (Weill Cornell Medicine) for assistance with automated microscopy and image analysis.

Disclosure Statement: The authors declare no conflict of competing financial interests.

\section{Funding}

This work was supported by NIH grant [R01NS37918] (PL) and a grant from the Cure Alzheimer Fund [CAF182540-1] (FRM). 


\section{$\underline{\text { References }}$}

Bacskai, B.J., Kajdasz, S.T., Christie, R.H., Carter, C., Games, D., Seubert, P., Schenk, D., Hyman, B.T., 2001. Imaging of amyloid-beta deposits in brains of living mice permits direct observation of clearance of plaques with immunotherapy. Nat Med 7(3), 369-372.

Bertram, L., McQueen, M.B., Mullin, K., Blacker, D., Tanzi, R.E., 2007. Systematic metaanalyses of Alzheimer disease genetic association studies: the AlzGene database. Nat Genet 39(1), 17-23.

Boissonneault, V., Filali, M., Lessard, M., Relton, J., Wong, G., Rivest, S., 2009. Powerful beneficial effects of macrophage colony-stimulating factor on beta-amyloid deposition and cognitive impairment in Alzheimer's disease. Brain 132(Pt 4), 1078-1092.

Cataldo, A.M., Nixon, R.A., 1990. Enzymatically active lysosomal proteases are associated with amyloid deposits in Alzheimer brain. Proc Natl Acad Sci U S A 87(10), 3861-3865.

Chung, H., Brazil, M.I., Soe, T.T., Maxfield, F.R., 1999. Uptake, degradation, and release of fibrillar and soluble forms of Alzheimer's amyloid beta-peptide by microglial cells. J Biol Chem 274(45), 32301-32308.

Dimitrova, M.B., Atanasova, D.Y., Lazarov, N.E., 2017. Tripeptidyl Peptidase I and Its Role in Neurodegenerative and Tumor Diseases, in: Chakraborti, S., Dhalla, N.S. (Eds.), Pathophysiological Aspects of Proteases. Springer Singapore, Singapore, pp. 147-160. Dominguez, D., Tournoy, J., Hartmann, D., Huth, T., Cryns, K., Deforce, S., Serneels, L., Camacho, I.E., Marjaux, E., Craessaerts, K., Roebroek, A.J., Schwake, M., D'Hooge, R., Bach, P., Kalinke, U., Moechars, D., Alzheimer, C., Reiss, K., Saftig, P., De Strooper, B., 2005. Phenotypic and biochemical analyses of BACE1- and BACE2-deficient mice. J Biol Chem 280(35), 30797-30806.

ElAli, A., Rivest, S., 2016. Microglia in Alzheimer's disease: A multifaceted relationship. Brain Behav Immun 55, 138-150.

Embury, C.M., Dyavarshetty, B., Lu, Y., Wiederin, J.L., Ciborowski, P., Gendelman, H.E., Kiyota, T., 2017. Cathepsin B Improves B-Amyloidosis and Learning and Memory in Models of Alzheimer's Disease. J Neuroimmune Pharmacol 12(2), 340-352.

Erblich, B., Zhu, L., Etgen, A.M., Dobrenis, K., Pollard, J.W., 2011. Absence of colony stimulation factor-1 receptor results in loss of microglia, disrupted brain development and olfactory deficits. PLoS One 6(10), e26317.

Ezaki, J., Takeda-Ezaki, M., Oda, K., Kominami, E., 2000. Characterization of endopeptidase activity of tripeptidyl peptidase-I/CLN2 protein which is deficient in classical late infantile neuronal ceroid lipofuscinosis. Biochem Biophys Res Commun 268(3), 904-908.

Giulian, D., Baker, T.J., 1986. Characterization of ameboid microglia isolated from developing mammalian brain. J Neurosci 6(8), 2163-2178.

Glenner, G.G., Wong, C.W., 1984. Alzheimer's disease: initial report of the purification and characterization of a novel cerebrovascular amyloid protein. Biochem Biophys Res Commun 120(3), 885-890.

Golabek, A.A., Dolzhanskaya, N., Walus, M., Wisniewski, K.E., Kida, E., 2008. Prosegment of tripeptidyl peptidase $\mathrm{I}$ is a potent, slow-binding inhibitor of its cognate enzyme. J Biol Chem 283(24), 16497-16504.

Golabek, A.A., Wujek, P., Walus, M., Bieler, S., Soto, C., Wisniewski, K.E., Kida, E., 2004. Maturation of human tripeptidyl-peptidase I in vitro. J Biol Chem 279(30), 31058-31067. 
Guhaniyogi, J., Sohar, I., Das, K., Stock, A.M., Lobel, P., 2009. Crystal structure and autoactivation pathway of the precursor form of human tripeptidyl-peptidase 1, the enzyme deficient in late infantile ceroid lipofuscinosis. J Biol Chem 284(6), 3985-3997.

Hamazaki, H., 1996. Cathepsin D is involved in the clearance of Alzheimer's beta-amyloid protein. FEBS Lett 396(2-3), 139-142.

Hopperton, K.E., Mohammad, D., Trépanier, M.O., Giuliano, V., Bazinet, R.P., 2018. Markers of microglia in post-mortem brain samples from patients with Alzheimer's disease: a systematic review. Mol Psychiatry 23(2), 177-198.

Junaid, M.A., Wu, G., Pullarkat, R.K., 2000. Purification and characterization of bovine brain lysosomal pepstatin-insensitive proteinase, the gene product deficient in the human late-infantile neuronal ceroid lipofuscinosis. J Neurochem 74(1), 287-294.

Kida, E., Golabek, A.A., Walus, M., Wujek, P., Kaczmarski, W., Wisniewski, K.E., 2001. Distribution of tripeptidyl peptidase I in human tissues under normal and pathological conditions. J Neuropathol Exp Neurol 60(3), 280-292.

Kunkle, B.W., Vardarajan, B.N., Naj, A.C., Whitehead, P.L., Rolati, S., Slifer, S., Carney, R.M., Cuccaro, M.L., Vance, J.M., Gilbert, J.R., Wang, L.S., Farrer, L.A., Reitz, C., Haines, J.L., Beecham, G.W., Martin, E.R., Schellenberg, G.D., Mayeux, R.P., Pericak-Vance, M.A., 2017. Early-Onset Alzheimer Disease and Candidate Risk Genes Involved in Endolysosomal Transport. JAMA Neurol.

Lanoiselée, H.M., Nicolas, G., Wallon, D., Rovelet-Lecrux, A., Lacour, M., Rousseau, S., Richard, A.C., Pasquier, F., Rollin-Sillaire, A., Martinaud, O., Quillard-Muraine, M., de la Sayette, V., Boutoleau-Bretonniere, C., Etcharry-Bouyx, F., Chauviré, V., Sarazin, M., le Ber, I., Epelbaum, S., Jonveaux, T., Rouaud, O., Ceccaldi, M., Félician, O., Godefroy, O., Formaglio, M., Croisile, B., Auriacombe, S., Chamard, L., Vincent, J.L., Sauvée, M., Marelli-Tosi, C., Gabelle, A., Ozsancak, C., Pariente, J., Paquet, C., Hannequin, D., Campion, D., project, c.o.t.C.M., 2017. APP, PSEN1, and PSEN2 mutations in early-onset Alzheimer disease: A genetic screening study of familial and sporadic cases. PLoS Med 14(3), e1002270.

Li, F., Calingasan, N.Y., Yu, F., Mauck, W.M., Toidze, M., Almeida, C.G., Takahashi, R.H., Carlson, G.A., Flint Beal, M., Lin, M.T., Gouras, G.K., 2004. Increased plaque burden in brains of APP mutant MnSOD heterozygous knockout mice. J Neurochem 89(5), 1308-1312.

Lin, L., Lobel, P., 2001. Production and characterization of recombinant human CLN2 protein for enzyme-replacement therapy in late infantile neuronal ceroid lipofuscinosis. Biochem $\mathbf{J}$ 357(Pt 1), 49-55.

Lin, L., Sohar, I., Lackland, H., Lobel, P., 2001. The human CLN2 protein/tripeptidyl-peptidase I is a serine protease that autoactivates at acidic pH. J Biol Chem 276(3), 2249-2255.

Lévy, F., Burri, L., Morel, S., Peitrequin, A.L., Lévy, N., Bachi, A., Hellman, U., Van den Eynde, B.J., Servis, C., 2002. The final N-terminal trimming of a subaminoterminal prolinecontaining HLA class I-restricted antigenic peptide in the cytosol is mediated by two peptidases. J Immunol 169(8), 4161-4171.

Mackay, E.A., Ehrhard, A., Moniatte, M., Guenet, C., Tardif, C., Tarnus, C., Sorokine, O., Heintzelmann, B., Nay, C., Remy, J.M., Higaki, J., Van Dorsselaer, A., Wagner, J., Danzin, C., Mamont, P., 1997. A possible role for cathepsins D, E, and B in the processing of beta-amyloid precursor protein in Alzheimer's disease. Eur J Biochem 244(2), 414-425.

Majumdar, A., Capetillo-Zarate, E., Cruz, D., Gouras, G.K., Maxfield, F.R., 2011. Degradation of Alzheimer's amyloid fibrils by microglia requires delivery of $\mathrm{ClC}-7$ to lysosomes. Mol Biol Cell 22(10), 1664-1676. 
Majumdar, A., Chung, H., Dolios, G., Wang, R., Asamoah, N., Lobel, P., Maxfield, F.R., 2008. Degradation of fibrillar forms of Alzheimer's amyloid beta-peptide by macrophages. Neurobiol Aging 29(5), 707-715.

Majumdar, A., Cruz, D., Asamoah, N., Buxbaum, A., Sohar, I., Lobel, P., Maxfield, F.R., 2007. Activation of microglia acidifies lysosomes and leads to degradation of Alzheimer amyloid fibrils. Mol Biol Cell 18(4), 1490-1496.

Masters, C.L., Bateman, R., Blennow, K., Rowe, C.C., Sperling, R.A., Cummings, J.L., 2015. Alzheimer's disease. Nat Rev Dis Primers 1, 15056.

Mawuenyega, K.G., Sigurdson, W., Ovod, V., Munsell, L., Kasten, T., Morris, J.C., Yarasheski, K.E., Bateman, R.J., 2010. Decreased clearance of CNS beta-amyloid in Alzheimer's disease. Science 330(6012), 1774.

Mucke, L., Masliah, E., Yu, G.Q., Mallory, M., Rockenstein, E.M., Tatsuno, G., Hu, K., Kholodenko, D., Johnson-Wood, K., McConlogue, L., 2000. High-level neuronal expression of abeta 1-42 in wild-type human amyloid protein precursor transgenic mice: synaptotoxicity without plaque formation. J Neurosci 20(11), 4050-4058.

Mueller-Steiner, S., Zhou, Y., Arai, H., Roberson, E.D., Sun, B., Chen, J., Wang, X., Yu, G., Esposito, L., Mucke, L., Gan, L., 2006. Antiamyloidogenic and neuroprotective functions of cathepsin B: implications for Alzheimer's disease. Neuron 51(6), 703-714.

Nakajima, K., Hamanoue, M. Shimojo, M., Takei, N. and Kohsaka, S., 1989. Characterization of microglia isolated from a primary culture of embryonic rat brain by a simplified method.

Biomed. Res. 10, 411-423.

Nemtsova, Y., Wiseman, J.A., El-Banna, M., Lobel, P., Sleat, D.E., 2018. Inducible transgenic expression of tripeptidyl peptidase 1 in a mouse model of late-infantile neuronal ceroid lipofuscinosis. PLoS One 13(2), e0192286.

Paresce, D.M., Chung, H., Maxfield, F.R., 1997. Slow degradation of aggregates of the Alzheimer's disease amyloid beta-protein by microglial cells. J Biol Chem 272(46), 2939029397.

Paresce, D.M., Ghosh, R.N., Maxfield, F.R., 1996. Microglial cells internalize aggregates of the Alzheimer's disease amyloid beta-protein via a scavenger receptor. Neuron 17(3), 553-565.

Pipalia, N.H., Subramanian, K., Mao, S., Ralph, H., Hutt, D.M., Scott, S.M., Balch, W.E., Maxfield, F.R., 2017. Histone deacetylase inhibitors correct the cholesterol storage defect in most Niemann-Pick C1 mutant cells. J Lipid Res 58(4), 695-708.

Saido, T., Leissring, M.A., 2012. Proteolytic Degradation of Amyloid beta-Protein. Cold Spring Harb Perspect Med 2(6), a006379.

Sanchez-Carbayo, M., Belbin, T.J., Scotlandi, K., Prystowsky, M., Baldini, N., Childs, G., Cordon-Cardo, C., 2003. Expression profiling of osteosarcoma cells transfected with MDR1 and NEO genes: regulation of cell adhesion, apoptosis, and tumor suppression-related genes. Lab Invest 83(4), 507-517.

Schenk, D., Barbour, R., Dunn, W., Gordon, G., Grajeda, H., Guido, T., Hu, K., Huang, J., Johnson-Wood, K., Khan, K., Kholodenko, D., Lee, M., Liao, Z., Lieberburg, I., Motter, R., Mutter, L., Soriano, F., Shopp, G., Vasquez, N., Vandevert, C., Walker, S., Wogulis, M., Yednock, T., Games, D., Seubert, P., 1999. Immunization with amyloid-beta attenuates Alzheimer-disease-like pathology in the PDAPP mouse. Nature 400(6740), 173-177.

Schindelin, J., Arganda-Carreras, I., Frise, E., Kaynig, V., Longair, M., Pietzsch, T., Preibisch, S., Rueden, C., Saalfeld, S., Schmid, B., Tinevez, J.Y., White, D.J., Hartenstein, V., Eliceiri, K., 
Tomancak, P., Cardona, A., 2012. Fiji: an open-source platform for biological-image analysis. Nat Methods 9(7), 676-682.

Schulz, A., Ajayi, T., Specchio, N., de Los Reyes, E., Gissen, P., Ballon, D., Dyke, J.P., Cahan, H., Slasor, P., Jacoby, D., Kohlschütter, A., Group, C.S., 2018. Study of Intraventricular Cerliponase Alfa for CLN2 Disease. N Engl J Med 378(20), 1898-1907.

Sleat, D.E., Donnelly, R.J., Lackland, H., Liu, C.G., Sohar, I., Pullarkat, R.K., Lobel, P., 1997. Association of mutations in a lysosomal protein with classical late-infantile neuronal ceroid lipofuscinosis. Science 277(5333), 1802-1805.

Sleat, D.E., El-Banna, M., Sohar, I., Kim, K.H., Dobrenis, K., Walkley, S.U., Lobel, P., 2008. Residual levels of tripeptidyl-peptidase I activity dramatically ameliorate disease in late-infantile neuronal ceroid lipofuscinosis. Mol Genet Metab 94(2), 222-233.

Sleat, D.E., Wiseman, J.A., El-Banna, M., Kim, K.H., Mao, Q., Price, S., Macauley, S.L., Sidman, R.L., Shen, M.M., Zhao, Q., Passini, M.A., Davidson, B.L., Stewart, G.R., Lobel, P., 2004. A mouse model of classical late-infantile neuronal ceroid lipofuscinosis based on targeted disruption of the CLN2 gene results in a loss of tripeptidyl-peptidase I activity and progressive neurodegeneration. J Neurosci 24(41), 9117-9126.

Sohar, I., Lin, L., Lobel, P., 2000. Enzyme-based diagnosis of classical late infantile neuronal ceroid lipofuscinosis: comparison of tripeptidyl peptidase I and pepstatin-insensitive protease assays. Clin Chem 46(7), 1005-1008.

Solé-Domènech, S., Cruz, D.L., Capetillo-Zarate, E., Maxfield, F.R., 2016. The endocytic pathway in microglia during health, aging and Alzheimer's disease. Ageing Res Rev 32, 89-103. Solé-Domènech, S., Rojas, A.V., Maisuradze, G.G., Scheraga, H.A., Lobel, P., Maxfield, F.R., 2018. Lysosomal enzyme tripeptidyl peptidase 1 destabilizes fibrillar A $\beta$ by multiple endoproteolytic cleavages within the $\beta$-sheet domain. Proc Natl Acad Sci U S A 115(7), 14931498.

Song, W., Wang, F., Savini, M., Ake, A., di Ronza, A., Sardiello, M., Segatori, L., 2013. TFEB regulates lysosomal proteostasis. Hum Mol Genet 22(10), 1994-2009.

Soulet, D., Rivest, S., 2008. Microglia. Curr Biol 18(12), R506-508.

Sun, B., Zhou, Y., Halabisky, B., Lo, I., Cho, S.H., Mueller-Steiner, S., Devidze, N., Wang, X., Grubb, A., Gan, L., 2008. Cystatin C-cathepsin B axis regulates amyloid beta levels and associated neuronal deficits in an animal model of Alzheimer's disease. Neuron 60(2), 247-257. Taipa, R., Brochado, P., Robinson, A., Reis, I., Costa, P., Mann, D.M., Melo Pires, M., Sousa, N., 2017. Patterns of Microglial Cell Activation in Alzheimer Disease and Frontotemporal Lobar Degeneration. Neurodegener Dis 17(4-5), 145-154.

Takata, K., Kitamura, Y., Yanagisawa, D., Morikawa, S., Morita, M., Inubushi, T., Tsuchiya, D., Chishiro, S., Saeki, M., Taniguchi, T., Shimohama, S., Tooyama, I., 2007. Microglial transplantation increases amyloid-beta clearance in Alzheimer model rats. FEBS Lett 581(3), 475-478.

Tanzi, R.E., 2012. The genetics of Alzheimer disease. Cold Spring Harb Perspect Med 2(10). Tian, Y., Sohar, I., Taylor, J.W., Lobel, P., 2006. Determination of the substrate specificity of tripeptidyl-peptidase I using combinatorial peptide libraries and development of improved fluorogenic substrates. J Biol Chem 281(10), 6559-6572.

Vines, D., Warburton, M.J., 1998. Purification and characterisation of a tripeptidyl aminopeptidase I from rat spleen. Biochim Biophys Acta 1384(2), 233-242.

Wang, C., Sun, B., Zhou, Y., Grubb, A., Gan, L., 2012. Cathepsin B degrades amyloid- $\beta$ in mice expressing wild-type human amyloid precursor protein. J Biol Chem 287(47), 39834-39841. 
Xiao, Q., Yan, P., Ma, X., Liu, H., Perez, R., Zhu, A., Gonzales, E., Burchett, J.M., Schuler, D.R., Cirrito, J.R., Diwan, A., Lee, J.M., 2014. Enhancing astrocytic lysosome biogenesis facilitates $\mathrm{A} \beta$ clearance and attenuates amyloid plaque pathogenesis. J Neurosci 34(29), 96079620.

Yang, D.S., Stavrides, P., Mohan, P.S., Kaushik, S., Kumar, A., Ohno, M., Schmidt, S.D., Wesson, D., Bandyopadhyay, U., Jiang, Y., Pawlik, M., Peterhoff, C.M., Yang, A.J., Wilson, D.A., St George-Hyslop, P., Westaway, D., Mathews, P.M., Levy, E., Cuervo, A.M., Nixon, R.A., 2011. Reversal of autophagy dysfunction in the TgCRND8 mouse model of Alzheimer's disease ameliorates amyloid pathologies and memory deficits. Brain 134(Pt 1), 258-277.

Supplemental Table 1. Genotype, Age, Sex, And Enzyme Activity of mice used for Thio-S plaque evaluation in figure 5. Enzyme activity is normalized to protein levels and is expressed as arbitrary units.

\begin{tabular}{|c|c|c|c|c|c|c|c|c|c|}
\hline 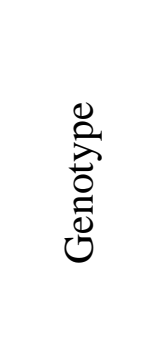 & 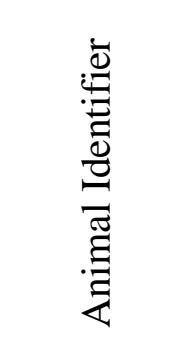 & 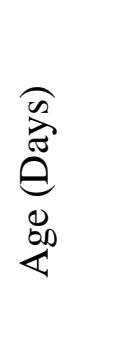 & 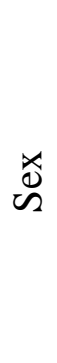 & 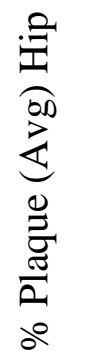 & 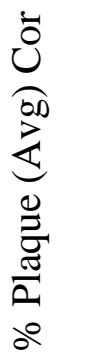 & 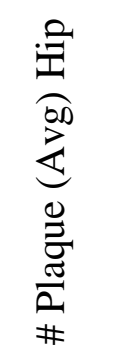 & 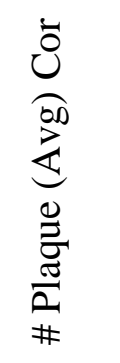 & $\vec{\rho}$ & 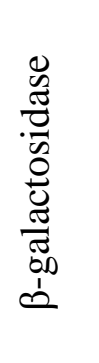 \\
\hline $\mathrm{Tg}+(\mathrm{f} / \mathrm{f})$ & $6736-37 \mathrm{~A}$ & 306 & $\mathrm{~F}$ & 1.08 & 0.29 & 79.00 & 79.00 & 7.4 & 307 \\
\hline $\mathrm{Tg}+(\mathrm{f} / \mathrm{f})$ & 6734 & 306 & $\mathrm{~F}$ & 1.49 & 0.26 & 83.67 & 83.67 & 6.9 & 298 \\
\hline $\mathrm{Tg}+(\mathrm{f} / \mathrm{f})$ & 6729 & 306 & $\mathrm{M}$ & 1.13 & 0.27 & 86.00 & 86.00 & 7.5 & 276 \\
\hline $\mathrm{Tg}+(\mathrm{f} / \mathrm{f})$ & 6733 & 306 & $\mathrm{M}$ & 1.19 & 0.36 & 81.67 & 81.67 & 7.1 & 307 \\
\hline $\mathrm{Tg}+(\mathrm{f} / \mathrm{f})$ & 7109 & 313 & $\mathrm{~F}$ & 1.31 & 0.27 & 109.33 & 109.33 & 7.4 & 293 \\
\hline $\mathrm{Tg}+(\mathrm{f} / \mathrm{f})$ & 7102 & 313 & M & 1.80 & 0.42 & 110.67 & 110.67 & 8.2 & 300 \\
\hline $\mathrm{Tg}+(\mathrm{f} / \mathrm{f})$ & 6720 & 336 & $\mathrm{~F}$ & 1.15 & 0.32 & 82.00 & 82.00 & 8.4 & 327 \\
\hline$T g+(f / f)$ & 6723 & 336 & $\mathrm{~F}$ & 2.09 & 0.35 & 70.67 & 70.67 & 7.8 & 318 \\
\hline $\mathrm{Tg}+(\mathrm{f} / \mathrm{f})$ & 6724 & 336 & $\mathrm{~F}$ & 1.07 & 0.29 & 94.33 & 94.33 & 7.2 & 305 \\
\hline $\mathrm{Tg}+(\mathrm{f} / \mathrm{f})$ & 6717 & 336 & $\mathrm{M}$ & 1.27 & 0.23 & 83.33 & 83.33 & 8.7 & 327 \\
\hline $\mathrm{Tg}+(\mathrm{f} / \mathrm{f})$ & 6718 & 336 & $\mathrm{M}$ & 1.82 & 0.40 & 108.67 & 108.67 & 8.7 & 306 \\
\hline $\mathrm{Tg}+(\mathrm{f} / \mathrm{f})$ & 7977 & 337 & $\mathrm{M}$ & 1.75 & 0.41 & 129.33 & 129.33 & 8.6 & 334 \\
\hline $\mathrm{Tg}+(\mathrm{f} / \mathrm{f})$ & 7969 & 343 & $\mathrm{M}$ & 1.68 & 0.31 & 115.33 & 115.33 & 9.1 & 335 \\
\hline $\mathrm{Tg}+(\mathrm{f} / \mathrm{f})$ & $7856-58 C$ & 355 & $\mathrm{M}$ & 1.32 & 0.33 & 87.00 & 87.00 & 9.1 & 352 \\
\hline $\mathrm{Tg}+(\mathrm{f} / \mathrm{f})$ & $7755-57 \mathrm{C}$ & 363 & $\mathrm{M}$ & 1.72 & 0.33 & 117.33 & 117.33 & 10.0 & 379 \\
\hline $\mathrm{Tg}+(\mathrm{f} / \mathrm{f})$ & 7846 & 365 & $\mathrm{~F}$ & 2.31 & 0.25 & 102.00 & 102.00 & 9.1 & 366 \\
\hline $\mathrm{Tg}+(\mathrm{f} / \mathrm{f})$ & $7745 \mathrm{~A}$ & 366 & $\mathrm{~F}$ & 1.66 & 0.44 & 108.33 & 108.33 & 65.3 & 330 \\
\hline $\mathrm{Tg}+(\mathrm{f} / \mathrm{f})$ & 6444 & 415 & $\mathrm{M}$ & 2.26 & 0.40 & 144.50 & 144.50 & 8.4 & 337 \\
\hline $\mathrm{Tg}+(\mathrm{f} / \mathrm{f})$ & 6002 & 476 & $\mathrm{~F}$ & 2.60 & 0.51 & 190.67 & 190.67 & 9.0 & 348 \\
\hline $\mathrm{Tg}+(\mathrm{f} / \mathrm{f})$ & 6005 & 476 & $\mathrm{~F}$ & 2.58 & 0.51 & 182.00 & 182.00 & 8.4 & 328 \\
\hline
\end{tabular}




\begin{tabular}{|cccccrrrrr|}
\hline $\mathrm{Tg}+(+/+)$ & 6195 & 316 & $\mathrm{M}$ & 1.50 & 0.21 & 79.00 & 79.00 & 98.6 & 294 \\
$\mathrm{Tg}+(\mathrm{f} /+)$ & 7976 & 337 & $\mathrm{M}$ & 1.60 & 0.35 & 108.00 & 108.00 & 66.6 & 327 \\
$\mathrm{Tg}+(\mathrm{f} /+)$ & 7968 & 343 & $\mathrm{M}$ & 1.20 & 0.28 & 110.67 & 110.67 & 62.7 & 300 \\
$\mathrm{Tg}+(\mathrm{f} /+)$ & 7947 & 354 & $\mathrm{M}$ & 1.61 & 0.32 & 106.33 & 106.33 & 68.7 & 340 \\
$\mathrm{Tg}+(\mathrm{f} /+)$ & $7755-57 \mathrm{~A}$ & 363 & $\mathrm{M}$ & 1.35 & 0.32 & 98.00 & 98.00 & 74.4 & 351 \\
$\mathrm{Tg}+(\mathrm{f} /+)$ & $7840-7889$ & 365 & $\mathrm{~F}$ & 1.29 & 0.23 & 86.67 & 86.67 & 65.4 & 343 \\
$\mathrm{Tg}+(\mathrm{f} /+)$ & $7745 \mathrm{~B}$ & 366 & $\mathrm{~F}$ & 1.12 & 0.33 & 81.33 & 81.33 & 10.0 & 387 \\
$\mathrm{Tg}+(\mathrm{f} /+)$ & 5974 & 367 & $\mathrm{M}$ & 1.40 & 0.21 & 94.00 & 94.00 & 60.8 & 283 \\
$\mathrm{Tg}+(+/+)$ & 5990 & 367 & $\mathrm{M}$ & 1.04 & 0.26 & 114.67 & 114.67 & 114.3 & 309 \\
$\mathrm{Tg}+(\mathrm{f} /+)$ & 6710 & 392 & $\mathrm{~F}$ & 1.75 & 0.27 & 119.33 & 119.33 & 58.8 & 284 \\
$\mathrm{Tg}+(\mathrm{f} /+)$ & 6725 & 411 & $\mathrm{M}$ & 1.29 & 0.34 & 90.00 & 90.00 & 58.1 & 281 \\
$\mathrm{Tg}+(\mathrm{f} /+)$ & $5545-48 \mathrm{~A}$ & 444 & $\mathrm{~F}$ & 1.26 & 0.21 & 113.67 & 113.67 & 73.1 & 310 \\
$\mathrm{Tg}+(\mathrm{f} /+)$ & $5545-48 \mathrm{~B}$ & 444 & $\mathrm{~F}$ & 1.80 & 0.31 & 152.67 & 152.67 & 66.6 & 309 \\
$\mathrm{Tg}+(\mathrm{f} /+)$ & $5545-48 \mathrm{D}$ & 444 & $\mathrm{~F}$ & 1.50 & 0.28 & 111.33 & 111.33 & 76.8 & 335 \\
$\mathrm{Tg}+(\mathrm{f} /+)$ & $5543-44 \mathrm{~A}$ & 444 & $\mathrm{M}$ & 2.20 & 0.29 & 154.67 & 154.67 & 68.6 & 332 \\
$\mathrm{Tg}+(\mathrm{f} /+)$ & $5543-44 \mathrm{~B}$ & 444 & $\mathrm{M}$ & 2.06 & 0.42 & 160.00 & 160.00 & 53.6 & 349 \\
$\mathrm{Tg}+(\mathrm{f} /+)$ & $5984-85 \mathrm{~A}$ & 471 & $\mathrm{~F}$ & 1.50 & 0.31 & 136.00 & 136.00 & 65.5 & 305 \\
$\mathrm{Tg}+(\mathrm{f} /+)$ & $5984-85 \mathrm{~B}$ & 471 & $\mathrm{~F}$ & 1.53 & 0.22 & 143.33 & 143.33 & 60.2 & 276 \\
$\mathrm{Tg}+(+/+)$ & 5020 & 498 & $\mathrm{M}$ & 2.47 & 0.39 & 180.67 & 180.67 & 104.2 & 290 \\
\hline & & & & & & & & & \\
\hline $\mathrm{Tg}-(\mathrm{f} / \mathrm{f})$ & $6736-37 \mathrm{~B}$ & 306 & $\mathrm{~F}$ & 0.08 & 0.03 & 2.67 & 2.67 & 7.6 & 306 \\
$\mathrm{Tg}-(\mathrm{f} /+)$ & 7974 & 337 & $\mathrm{M}$ & 0.02 & 0.03 & 0.67 & 0.67 & 63.7 & 316 \\
$\mathrm{Tg}-(\mathrm{f} / \mathrm{f})$ & $7856-58 \mathrm{~B}$ & 355 & $\mathrm{M}$ & 0.02 & 0.00 & 0.67 & 0.67 & 9.4 & 356 \\
$\mathrm{Tg}-(\mathrm{f} / \mathrm{f})$ & $7847-48 \mathrm{~A}$ & 366 & $\mathrm{M}$ & 0.03 & 0.05 & 0.33 & 0.33 & 9.6 & 353 \\
$\mathrm{Tg}-(+/-)$ & $5545-48 \mathrm{C}$ & 444 & $\mathrm{~F}$ & 0.00 & 0.01 & 0.00 & 0.00 & 65.7 & 278 \\
$\mathrm{Tg}-(+/+)$ & $5023-24-25$ & 526 & $\mathrm{~F}$ & 0.02 & 0.01 & 1.33 & 1.33 & 115.7 & 258 \\
\hline
\end{tabular}

\section{Figure Legends:}

Figure 1. Addition of TPP1 to microglia enhances fA $\beta$ degradation. Primary murine microglia were incubated with $\mathrm{Cy} 3-\mathrm{fA} \beta$ for one hour and, where indicated, treated with $100 \mathrm{nM}$ purified proTPP1 for the duration of a 72 hour chase. Cells were PFA fixed and imaged by epifluorescence microscopy. The Cy3-fA $\beta$ intensity was measured for each cell for $\sim 190$ total cells (total from 3 separate experiments). Within 72 hours, treated microglia efficiently degraded $\mathrm{fA} \beta$, as measured by loss of $\mathrm{Cy} 3$ fluorescence, while degradation by untreated cells was limited. Bars are mean \pm SEM for all cells measured. $(\mathrm{P}=0.002)$

Figure 2. Degradation of internalized $f A \beta$ is blocked by a tripeptidyl peptidase inhibitor. J774A.1 macrophage cells (A) $(\mathrm{P}<1 \times 10)$, microglia treated with MCSF $(\mathrm{B})\left(\mathrm{P}=3.4 \times 10^{-9}\right)$ and U2OS-SRA cells $(C)\left(\mathrm{P}<1 \times 10^{-10}\right)$ were pre-treated for 1 hour with or without $50 \mu \mathrm{M}$ AAF-CMK. Subsequently, the cells were loaded with Cy3-fA $\beta$ for one hour and chased for 72 hours with or without AAF-CMK in the medium. Cells were PFA fixed and imaged by epifluorescence microscopy. The Cy3-fA $\beta$ intensity was measured for each cell for $\sim 120$ total cells (total from 3 
replicate experiments) per condition. The inhibitor-treated cells showed reduced fA $\beta$ degradation. Bars are mean \pm SEM for all cells measured.

Figure 3. Degradation of fA $\beta$ is blocked by RNAi knockdown of Tpp1 in U2OS-SRA cells. (A) TPP1 activity in cells incubated for 72 hours with indicated siRNA was measured in cell lysates. Enzyme activity (shown as arbitrary fluorescence units, AFU) was normalized to untreated cells ( $\mathrm{P}=0.0002)$. (B) The $\mathrm{Cy} 3-\mathrm{fA} \beta$ intensity was measured in untreated, mock (scrambled) siRNA-treated, and Tpp1 targeted siRNA-treated cells incubated with Cy3-fA $\beta$ followed by a 24 hour chase $(\mathrm{P}=0.0008)$. Uptake was not altered by RNAi treatment, so the combined average initial uptake is shown. Only the cells treated to knock down TPP1 expression did not degrade fA $\beta$ efficiently. Approximately 500 fixed cells (total for all conditions) were imaged by epifluorescence microscopy. Bars are mean \pm SEM for all cells measured.

Figure 4. MCSF-treated Tpp1 ${ }^{-/-}$microglia do not degrade fA $\beta$ efficiently. Microglia (MG) isolated from wildtype or Tpp $1^{-/}$mice pretreated with MCSF for 2 weeks were incubated with Cy3-fA $\beta$ ( $1 \mathrm{hr}$ ) followed by a $72 \mathrm{hr}$ chase in MCSF-containing medium. The Cy3-fA $\beta$ intensity was measured by epifluorescence microscopy for each fixed cell (50 cells per experiment, 3 replicates from one MG prep, for total $\sim 150$ cells per condition). MCSF-treated wild type microglia efficiently degraded $\mathrm{fA} \beta(\mathrm{P}=0.021)$ compared to limited $\mathrm{fA} \beta$ degradation by MCSFtreated Tpp1 ${ }^{-/-}$microglia. Bars are mean \pm SEM for all cells measured.

Figure 5. Reduced TPP1 activity increases plaque burden in AD mice. (A) Amyloid plaques in the brain were visualized by Thio-S staining in $\mathrm{Tg}+$ and $\mathrm{Tg}$ - mice that had $<10 \%$ or $50-100 \%$ TPP1 activity. Representative images of older Thio-S stained brain slices. (B) Percent plaque coverage of the hippocampus in mice age 300 days and older. Square blue symbols are Tg+ animals with $<10 \%$ TPP1 activity. Triangles are Tg+ mice with 50-100\% TPP1 activity (red, $T_{p p 1^{+/ f}}$; green, $\operatorname{Tpp}^{+/+}$). Bars show the SEM of the values from 3 individual slices (solid symbols, split symbols indicate animals for which only 2 slices were analyzed), $P=0.0153$. (C) The total number of Thio-S labeled plaques from the hippocampus of brain slices of mice 300 days of age and older. Symbols and bars are as described above (N.S. not significant, $\mathrm{P}=0.1058$ ). (D) Percent plaque coverage of the cortex in mice age 300 days and older. Symbols and bars are as described above $(\mathrm{P}=0.0254)$. (E) The total number of Thio-S labeled plaques from the cortex of brain slices of mice 300 days of age and older. Symbols and bars are as described above $(\mathrm{P}=0.0033)$. Statistical analysis conducted in GraphPad Prism 8.0 comparing Tg+ groups (ANCOVA Linear Regression), blue line for Tg+ animals with <10\% TPP1 activity and orange line for the combined group of Tg+ mice with 50-100\% TPP1 activity. 
Figure 1

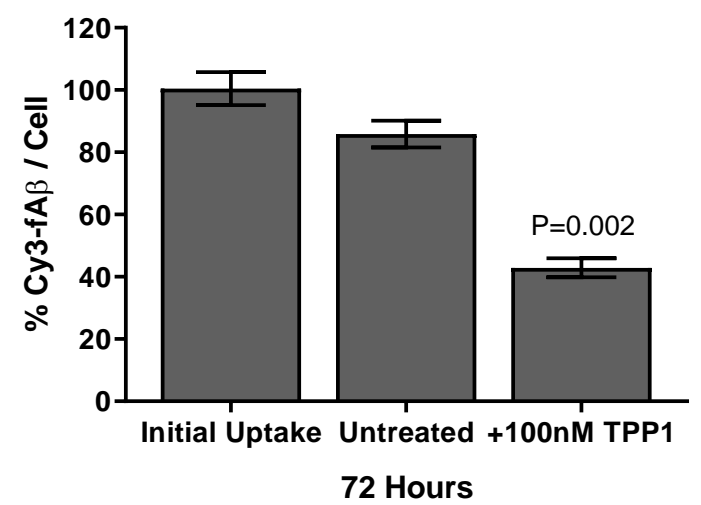


Figure 2

\section{A J774 Macrophages}

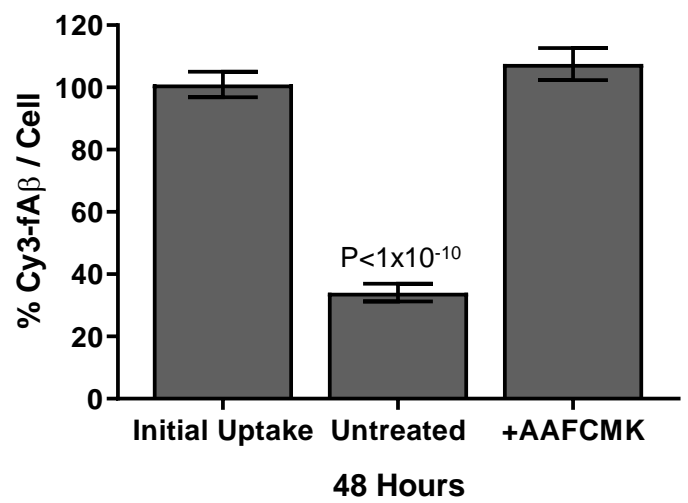

\section{B Microglia + MCSF}

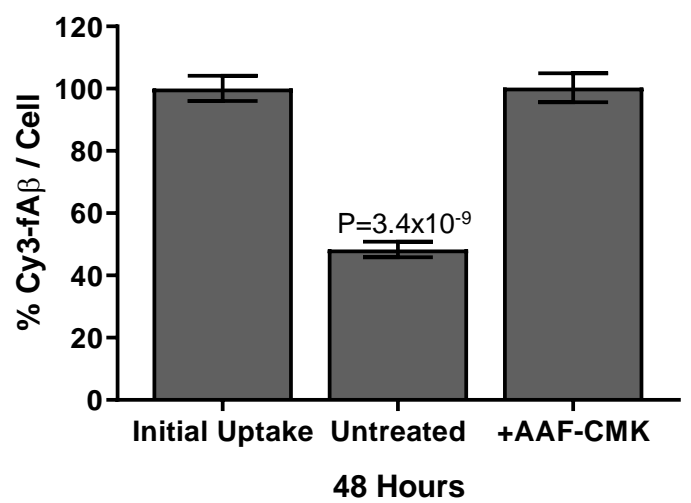

\section{U2OS-SRA}

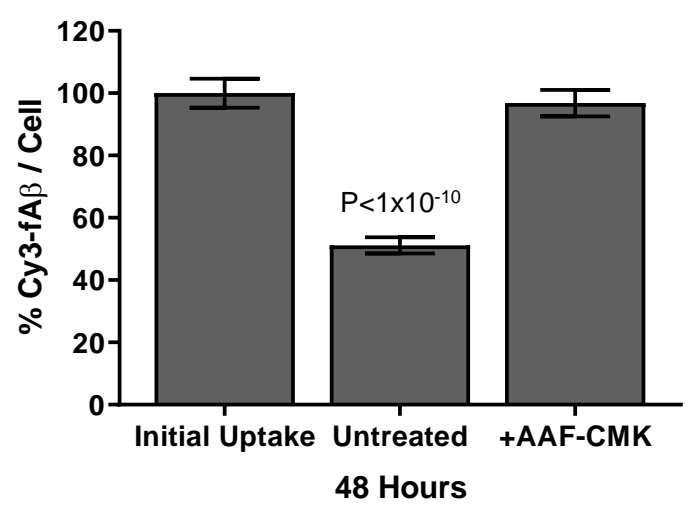


Figure 3

A

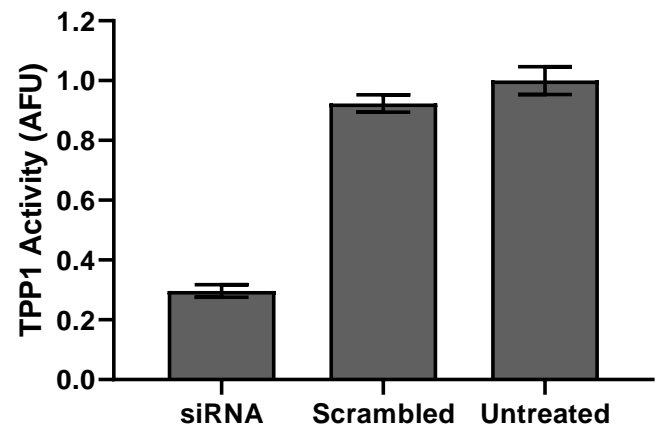

B

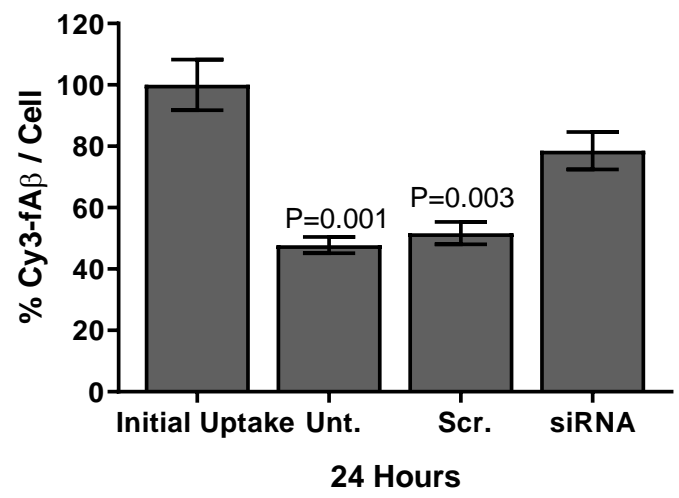


Figure 4

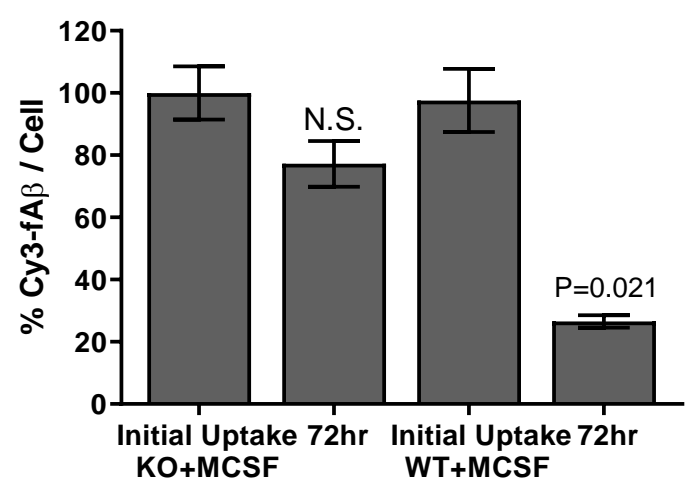


Figure 5

A

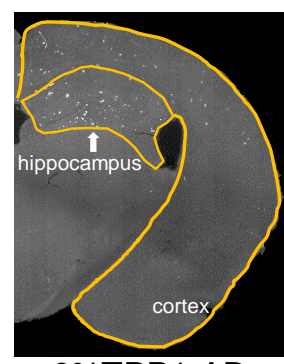

6\%TPP1-AD

476 days old

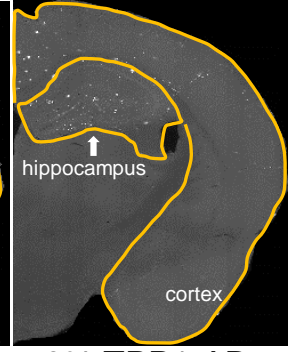

50\% TPP1-AD

471 days old
B

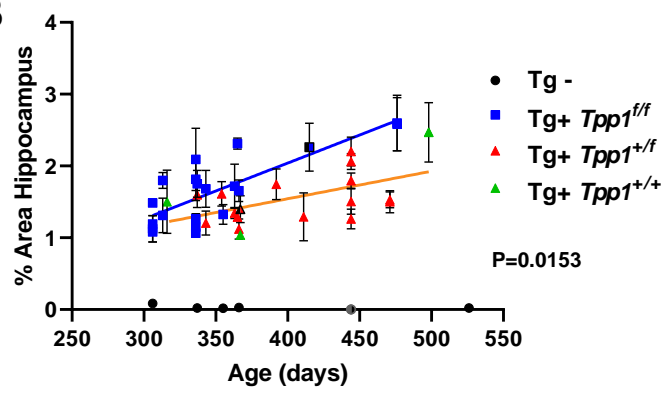

D

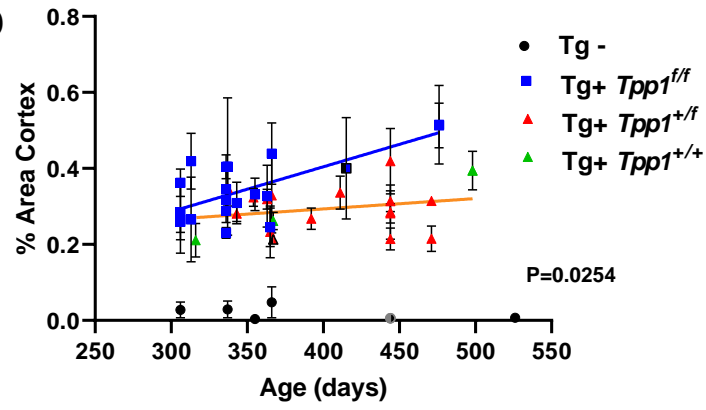

C

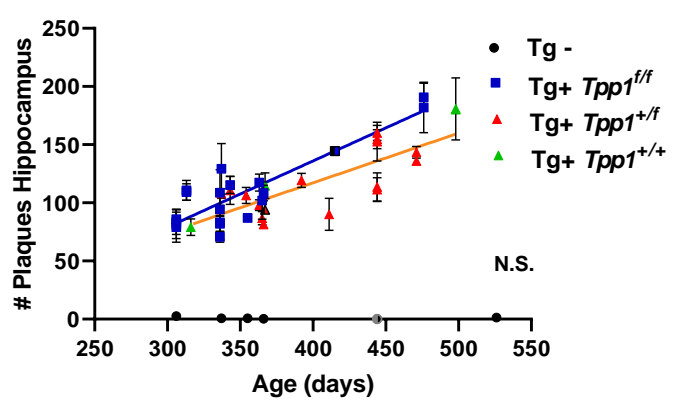

E

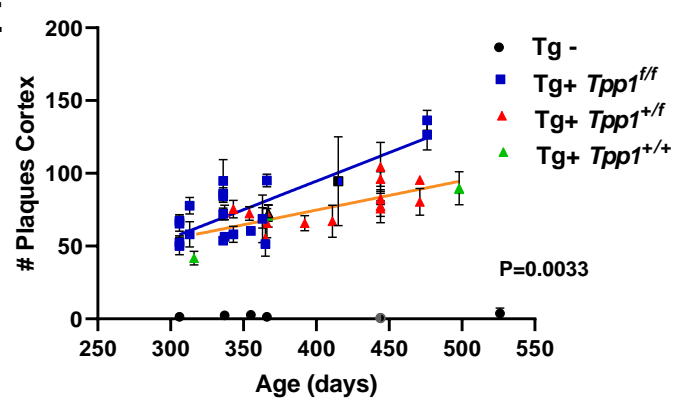

